\title{
Study on the natural bioactive peptides derived from milk
}

\author{
Peng Xiuming ${ }^{1, a}$, Yang Mei $^{1}$, Wu Junrui ${ }^{1}$, Wang Junyi ${ }^{1}$, Liu Biao ${ }^{2, b}$, Yue Xiqing ${ }^{1 *}$ \\ ${ }^{1}$ Food College of Shenyang Agricultural University, Liaoning Province, Shenyang, 110866 \\ ${ }^{2}$ Inner Mongolia Yili Industrial Group Limited by Share Ltd, Inner Mongolia, Hohhot, 010050 \\ aemail:547832398@qq.com
}

Keywords: Milk; Ultrafiltration; Natural active peptides; Process; Membrane flux

Abstract. In this study, we use the technology of ultrafiltration to separate the natural active peptides from milk, and optimize the conditions of ultrafiltration. The density of the natural bioactive peptides could be assayed through Biuret method. The results showed that the optimized separation conditions of ultrafiltration are as follows: the temperature $25^{\circ} \mathrm{C}$, pressure $0.25 \mathrm{MPa}$, time $30 \mathrm{~min}$ and $\mathrm{pH} \mathrm{7,} \mathrm{and} \mathrm{the} \mathrm{membrane} \mathrm{flux} \mathrm{can} \mathrm{reach} 14.24 \mathrm{~L} / \mathrm{m}^{2} \cdot \mathrm{h}$. The concentration of active peptide is $3.78 \mathrm{mg} / \mathrm{g}$ by gel filtration chromatography. The method of separating and purifying the natural active peptide from bovine milk has been preliminarily established, which provides a useful exploration for developing functional food and nutritional factors with medicinal value.

\section{Introduction}

Peptides Bioactive (BAP) is a kind of compound with biological function, which is less than $6000 \mathrm{u}$. The molecular structure of the complex is different, and it is a molecular polymer between amino acids and proteins [1]. Bioactive peptides have many biological activities, such as anti-microbial, anti-blood pressure (ACE), anti-oxidant, cellular immune regulation and tumor suppressor activity [2-4]. In particular, the studies of bioactive peptides in dairy resources are attracting attention in the food and pharmaceutical industry.

In recent years, the research on the activity of the enzymatic hydrolysis of milk in the domestic and overseas has been relatively mature [5], and the research on the natural bioactive peptides is little, such as separation of IGF-I from bovine colostrum by using acid and ethanol, and gel filtration chromatography and isolation and purification of bovine colostrum insulin-like growth factor by using hollow fiber ultrafiltration membrane, it also provides a theoretical basis for the extraction of the natural active peptides. In addition, whey milk nutrients accounted for 55\% [6], while whey is a by-product of cheese or casein production. Each production of $1 \mathrm{~kg}$ cheese need to consume $10 \mathrm{~kg}$ fresh milk, to separate the $9 \mathrm{~kg}$ byproduct whey, this part of the resources is not fully utilized. Whey protein has good biological activity and nutritional characteristics, and is rich in both sources. Therefore, we can use the existing resources and further research on the active peptides, which can realize the resource utilization and enhance the added value.

This study mainly on separation of bioactive peptides by 6ku ultrafiltration membrane ultrafiltration and SephadexG-25 dextran gel filtration chromatography technology, intends to establish the production of bioactive peptides of technology roadmap and related parameters. It provide a useful exploration for bioactive peptides of functional properties, single natural active peptide identification of follow-up studies and milk the further development of functional food and medicinal value of nutrient factors.

\section{Materials and Methods}

Materials. Fresh and non-pathogenic bacteria milk from Huishan dairy farms. 


\section{Experimental Methods}

Milk Pre-treatment. Fresh milk at $4^{\circ} \mathrm{C}$, 4000rpm conditions of centrifugal 30min, and carefully remove from the fat to get skim milk. Fresh milk at $4{ }^{\circ} \mathrm{C}$ and $4000 \mathrm{rpm}$ conditions of centrifugal $30 \mathrm{~min}$, carefully remove the fat to get skim milk. According to the characteristics of casein precipitation, with $1 \mathrm{~mol} / \mathrm{L} \mathrm{HCl} \mathrm{pH}$ is adjusted to 4.6 , still precipitated casein $30 \mathrm{~min}$, after filtration with sterile multilayer gauze to remove precipitation. Then with $1 \mathrm{~mol} / \mathrm{L} \mathrm{NaOH}$ was adjusted to neutral. The filtrate at $4^{\circ} \mathrm{C}$, centrifuged $15 \mathrm{~min}$ at $3000 \mathrm{rpm}$ conditions, and the supernatant is centrifuged twice in parallel.

Ultrafiltration [7]. The average relative molecular weight of bioactive peptides is less than $6000 \mathrm{u}$, so the ultrafiltration membranes with molecular weight of $6 \mathrm{ku}$ were used in this experiment. However, the supernatant contains a number of large molecular proteins, which can be removed by $0.45 \mathrm{um}$ micro porous membrane and $10 \mathrm{ku}$ ultrafiltration membrane filtration to remove the large molecular protein and to improve the efficiency of ultrafiltration, then carry out a formal experiment.

The ultrafiltration device is made up of nitrogen cylinder, pressure gauge, Millipore 8400 ultrafiltration cup (effective area $41.8 \mathrm{~cm}^{2}$ ), ultrafiltration membrane, magnetic force agitator, collecting device and so on. Pressure, time, temperature, $\mathrm{pH}$ and other factors have a vital influence on the flux of ultrafiltration membrane. According to the existing laboratory conditions, the experiments on membrane flux $(\mathrm{J})$ as experimental indexes, respectively to investigate pressure gradient $(0.05,0.10,0.15,0.20,0.15 \mathrm{MPa})$ and time $(30,60,90,120,150 \mathrm{~min})$, temperature $(10,20$, $\left.25,30,35^{\circ} \mathrm{C}\right), \mathrm{pH}(4,5,6,7,8)$ on the effects of the ultrafiltration. The flux formula as follow:

$$
\mathrm{J}=\mathrm{V} /(\mathrm{t} * \mathrm{~A})
$$

Type: $\mathrm{J}$ membrane flux $\left(\mathrm{L} / \mathrm{m}^{2} \cdot \mathrm{h}\right) ; \mathrm{V}$ the amount of fluid (L);

$$
\mathrm{T} \quad \text { ultrafiltration time }(\mathrm{h}) ; \text { A membrane area }\left(\mathrm{m}^{2}\right) \text {. }
$$

Concentration and Freeze Drying. The liquid is concentrated to the original volume to $1 / 2$ or $1 / 3$. The temperature control of the filtrate is $37-38^{\circ} \mathrm{C}$, and the time control is at $20-30 \mathrm{~min}$. The amount of the peptide solution is smooth in the frozen dry containers. Plastic wrap sealed containers, with small hole (to prevent contamination or splashing). In the ultra-low temperature refrigerator freezer $24 \mathrm{~h}$, frozen dry $24 \mathrm{~h}$ or $36 \mathrm{~h}$, the crude peptide powder was collected and stored at $-20^{\circ} \mathrm{C}$ refrigerator spare.

Gel Filtration Chromatography. SephadexG-25 column $(2.5 \mathrm{~cm} \times 60 \mathrm{~cm})$, at $4^{\circ} \mathrm{C}$, distilled water balance for the night. The crude peptide powder is equipped with $50 \mathrm{mg} / \mathrm{mL}$ solution, the sample volume is $0.50 \mathrm{~mL}$, and elution flow rate is $0.5 \mathrm{~mL} / \mathrm{min}$. According to Luo Wenfeng [8], it was found that the elution effect of using de-ionized water was better than that of phosphate. At the same time, the new reagent is not introduced, therefore, in this study, we used the de-ionized as the elution liquid $\mathrm{OD}_{2}$ o $_{0} \mathrm{~nm}$ value is measured by protein detector, and the operating temperature is $4^{\circ} \mathrm{C}$, eluent collected once every $5 \mathrm{~min}$. Elution solution is collected and lyophilized.

Determination of the Natural Active Peptides. The Bradford method [9,10].

\section{Results}

Effect of Pressure on the Membrane Flux. Experiments were carried out at the temperature $25^{\circ} \mathrm{C}$, the time $1 \mathrm{~h}, \mathrm{pH} 7$, to determine the effect of different pressure on the membrane flux. The result is shown in fig.1. 


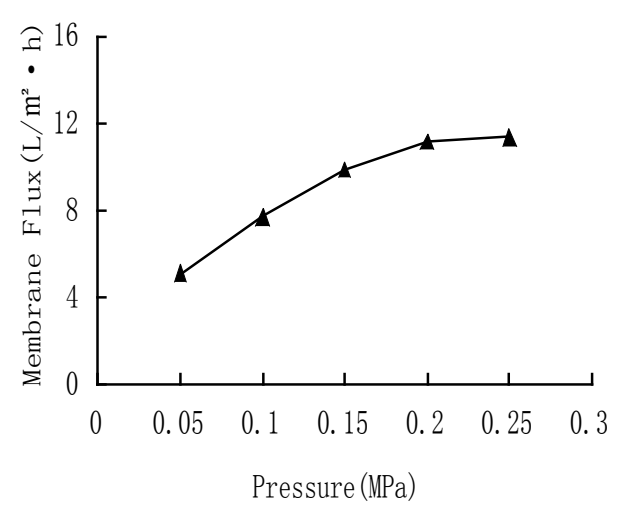

Fig.1 Effect of pressure on membrane flux

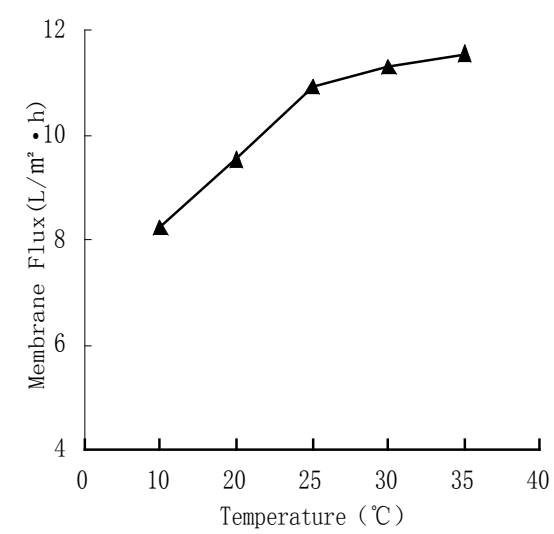

Fig.3 Effect of temperature on membrane flux

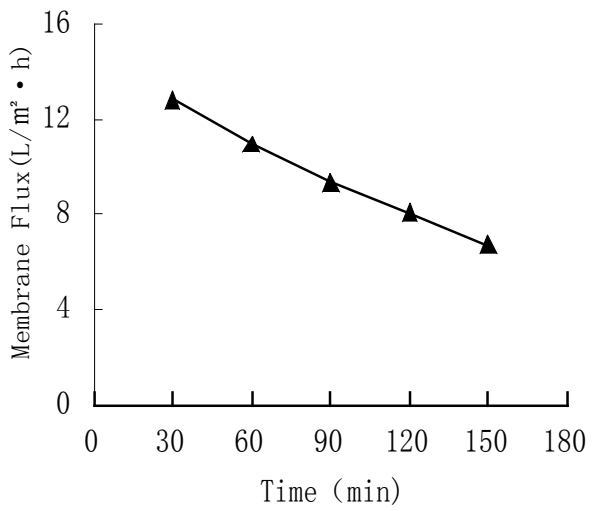

Fig.2 Effect of time on membrane flux

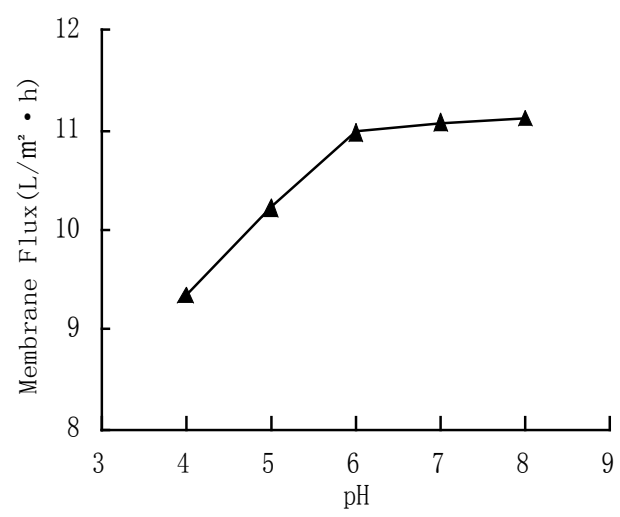

Fig.4 Effect of pH value on membrane flux

Fig. 1, in the $0.05-0.15 \mathrm{MPa}$ range, as the pressure increases, the membrane flux is also increasing. Pressure is the driving force in the ultrafiltration process, the greater the pressure, the more easy to pass through the material; with the increasing of pressure, the pollution layer is compacted, and the membrane pollution and the concentration polarization aggravate, which make the filtration rate increase slowly. This is the concentration polarization and gel layer theory [11]. Therefore, considering the energy saving and the flux of the two aspects, the selection of $0.15-0.25 \mathrm{MPa}$ is more suitable interval.

Time Influence on Membrane Flux. The effects of different time (interval 30min) on the membrane flux are measured at $25^{\circ} \mathrm{C}, 0.20 \mathrm{MPa}, 7 \mathrm{pH}$. The result is shown in fig. 2 .

Fig.2, the material liquid membrane flux is negatively correlated with the time, with the increasing time, the flux of the liquid film is gradually reduced, the concentration of the material is increasing with the extension of time, and ultrafiltration membrane pore size is contaminated. In the actual process of ultrafiltration, ultrafiltration membrane contamination cannot be avoided, but to keep clean and replace, therefore, the choice of 30-90 min is more appropriate interval.

Effect of Temperature on Membrane Flux. Experiment in the film can withstand the maximum temperature range, in $\mathrm{pH} 7$, pressure $0.20 \mathrm{MPa}$, and time $1 \mathrm{~h}$, the effects of different temperature on membrane flux are studied. The result is shown in fig.3.

As the temperature increases, the flux of membrane increased gradually, and the trend is relatively flat after $30^{\circ} \mathrm{C}$, because the material liquid decreases and the membrane permeability is improved with the temperature increasing. In the ultrafiltration operation, the activity of bioactive 
peptides will be affected by temperature, as the temperature rises; it is likely to lead to the degeneration of bioactive polypeptides [12]. At the same time, the temperature is too high to have a certain impact on the film material, and also increase the energy consumption. Therefore, the choice of $20-30^{\circ} \mathrm{C}$ is more appropriate interval.

Effects of pH Value on Membrane Flux. Under the condition pressure 0.20MPa, temperature $25^{\circ} \mathrm{C}$, time $1 \mathrm{~h}$, study on the effect of $\mathrm{pH}$ value on membrane flux. The result is shown in fig.4.

Fig. $4, \mathrm{pH}=4-6$, the membrane flux is on the rise; $\mathrm{PH}=6-8$, the membrane flux tends to be stable. It may be due to $\mathrm{pH}=4-5$ is closer to the isoelectric point of the proteins; the proteins in the material will adsorb to the ultrafiltration membrane and affect the membrane flux. Super filtrate $\mathrm{pH}$ over the general assembly so that the super filtrate will be introduced too many salt ions and produce a large base flavor. Therefore, the choice of 6.0-8.00 is more appropriate interval.

\section{Orthogonal Test Results Analysis}

Table1 Orthogonal test results and range analysis

\begin{tabular}{cccccc}
\hline \multirow{2}{*}{$\begin{array}{c}\text { Experiment } \\
\text { number }\end{array}$} & $\begin{array}{c}\mathrm{A} \\
\text { Pressure } \\
{[\mathrm{MPa}]}\end{array}$ & $\begin{array}{c}\text { Time } \\
{[\mathrm{min}]}\end{array}$ & $\begin{array}{c}\text { Temperature } \\
{\left[{ }^{\circ} \mathrm{C}\right]}\end{array}$ & $\begin{array}{c}\mathrm{D} \\
\mathrm{pH}\end{array}$ & $\begin{array}{c}\text { Membrane } \\
\text { flux } \\
{\left[\mathrm{L} / \mathrm{m}^{2} \cdot \mathrm{h}\right]}\end{array}$ \\
\hline 1 & $1(0.15)$ & $1(30)$ & $1(20)$ & 1 & 11.39 \\
2 & 1 & $2(60)$ & $2(25)$ & 2 & 10.84 \\
3 & 1 & $3(90)$ & $3(30)$ & 3 & 8.28 \\
4 & $2(0.20)$ & 1 & 2 & 3 & 12.91 \\
5 & 2 & 2 & 3 & 1 & 11.31 \\
6 & 2 & 3 & 1 & 2 & 9.38 \\
7 & $3(0.25)$ & 1 & 3 & 2 & 13.79 \\
8 & 3 & 2 & 1 & 3 & 12.45 \\
9 & 3 & 3 & 2 & 1 & 10.87 \\
$\mathrm{k} 1$ (mean) & 10.17 & 12.70 & 11.07 & 11.19 & \\
$\mathrm{k} 2$ (mean) & 11.2 & 11.53 & 11.54 & 11.34 & \\
$\mathrm{k} 3$ (mean) & 12.37 & 9.51 & 11.13 & 11.21 & \\
R & 2.20 & 3.19 & 0.47 & 0.15 & \\
\hline
\end{tabular}

In Table1, based on the single factor, the method of range analysis is used. According to the size of the factors, the test results were analyzed. Judging from the size of the R values in the table, the influence factors are sorted as time $>$ pressure $>$ temperature $>\mathrm{pH}$. The $\mathrm{R}$ value of $\mathrm{pH}$ is the smallest, which is used as the error term.

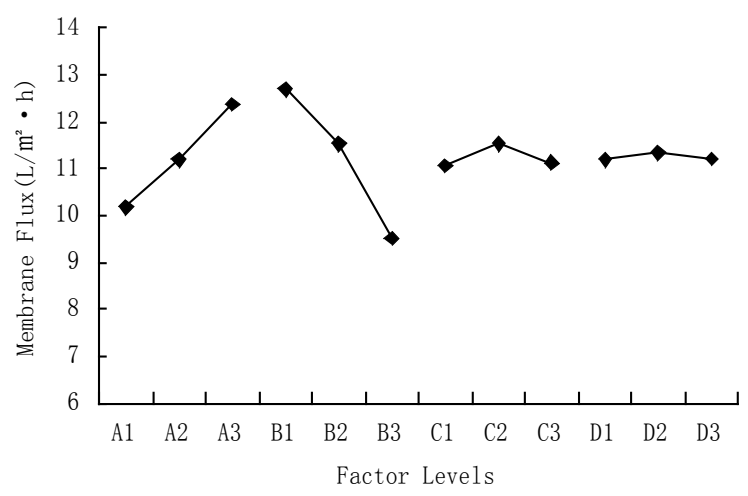

Fig.5 Relationship between factors and index 
In Fig.5, according to the size of the index, we can determine the optimal level and excellent combination. The optimal levels of pressure, time, temperature and $\mathrm{pH}$ we are $\mathrm{A}_{3}, \mathrm{~B}_{1}, \mathrm{C}_{2}, \mathrm{D}_{1}$ respectively. The excellent combination is $\mathrm{A}_{3} \mathrm{~B}_{1} \mathrm{C}_{2} \mathrm{D}_{1}$.

Table 2 Analysis of variance

\begin{tabular}{ccccccc}
\hline Error source & SS & df & MS & F & $\begin{array}{c}\text { F Threshold } \\
\text { value }\end{array}$ & Significant \\
\hline Temperature & 7.2689 & 2 & 3.6349 & 546.6000 & F0.01(2.2)=99 & $* *$ \\
Pressure & 15.6248 & 2 & 7.8124 & 1174.7960 & F0.05(2.2)=19 & $* *$ \\
Time & 0.3926 & 2 & 0.1963 & 29.5870 & & $*$ \\
Error & 0.0133 & 2 & 0.0067 & & & \\
Sum & 23.3005 & 8 & & & & \\
\hline
\end{tabular}

In table2, the effects of pressure, time and temperature on the separation of the natural active peptides are significantly influenced by 0.05 levels. At 0.01 levels, there is no significant difference in temperature; however, the effects of pressure and time are significant. In summary, the temperature $25^{\circ} \mathrm{C}$, pressure $0.25 \mathrm{MPa}$, time $30 \mathrm{~min}, \mathrm{pH} 7$, which is used as the optimal process parameters for the ultrafiltration.

The validation experiments are carried out under the optimal conditions: the pressure $0.25 \mathrm{MPa}$, temperature $25^{\circ} \mathrm{C}$, time $30 \mathrm{~min}$, and $\mathrm{pH} 7$. The test is repeated three times. The results show that the membrane flux is up to $14.24 \mathrm{~L} / \mathrm{m}^{2} \cdot \mathrm{h}$.

SephadexG-25 Separation and Purification Results. The crude peptide powder is dissolved into $50 \mathrm{mg} / \mathrm{mL}$ solution, and the sample volume is $0.50 \mathrm{~mL}$, elution flow rate is $0.5 \mathrm{~mL} / \mathrm{min}$ at $4{ }^{\circ} \mathrm{C}$, the result is shown in Fig.6.

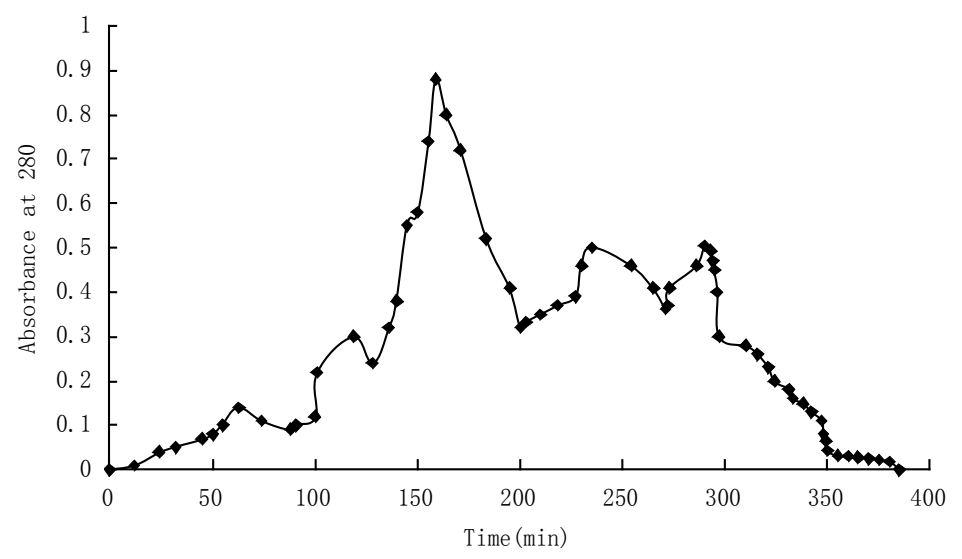

Fig.6 Gel chromatography of SephadexG-25

In Fig.6, the content of natural active peptides is determined by the collection of the dry powder of the elution peak: around 50 130 min, the content of active peptides in the frozen dry powder was very low, the part may have a loss of the natural active peptides; about 180 200 min, the content of active peptides in the frozen dry powder is $3.78 \mathrm{mg} / \mathrm{g}$; about $200 \sim 300 \mathrm{~min}$, the natural active peptide is not detected in the freeze-dried powder. The experimental results show that the proposed method has been successfully extracted from natural active peptides. 


\section{Conclusions}

In this study, we determine the best ultrafiltration process of separating natural active peptides from bovine milk: temperature $25{ }^{\circ} \mathrm{C}$, pressure $0.25 \mathrm{MPa}$, time $30 \mathrm{~min}$ and $\mathrm{pH} 7.0$. Membrane flux is up to $14.24 \mathrm{~L} / \mathrm{m}^{2} \cdot \mathrm{h}$; the content of natural active peptide was $3.78 \mathrm{mg} / \mathrm{g}$ by SephadexG-25; in this study, we establish a technical route for the separation and purification of the natural active peptides from bovine milk.

At present, the research of the natural bioactive peptides is still in the experimental stage. There is not a complete and effective method for purification; the functional characteristics and the difference of the active peptides obtained by enzymatic hydrolysis are needed to be further study. Meanwhile, the milk-derived bioactive peptides have a superior edible and medicinal value. This not only can increase the utilization rate and the value of the milk, but also can provide a theoretical basis for the future production of functional dairy products.

\section{Reference}

[1] Fengxia Cui. Ocean University of China, 2007. (In Chinese)

[2] LEE J K, PARK S C, et al. Biomaterials, 2014, 35(3): 1025-1039.

[3] DOYEN A, UDENIGWE C C, MITCHLL P L. Food Chemistry, 2014, 145: 66-76.

[4] TAHERI A, SABEENA FARVIN K H, JACOBSEN C. Food Chemistry, 2014,142: 318-326.

[5] Y. Mine, E. Li-Chan, B. Jiang (Eds.). Wiley-Blackwell, 2010.

[6] Yihong Bao, Lanwei Zhang, Qingquan Guo. Food Industry, 2000, 21(6): 5-7. (In Chinese)

[7] Jingfeng Zhang, Youbing Leng, Xiaodong Li. Food Industry, 2013, 34(4): 147-150. (In Chinese)

[8] Wenfeng Luo. Guangzhou: South China Science and Technology University, 2010. (In Chinese)

[9] Yuhong Yang, Jan Yang, Guangyu Zhang. Food Science and Technology, 2014, 39(7): 252-257.

(In Chinese)

[10] Wei Tong. Yang Ling: Northwest Agriculture and Forestry University, 2012. (In Chinese)

[11] Minghao Li, Xiaodong Li, Ling Zhang. Food Industry, 2014, 35(8): 115-119. (In Chinese)

[12] Qiuhua Bi. Nanning: Guangxi University, 2012. (In Chinese) 